\title{
Застосування біогерметика “Сульфакрилат” при виконанні лапароскопічних операцій з приводу перфорації виразки дванадцятипалої кишки
}

\author{
S. I. SAVOLIUK, O. H. SHEPETKO-DOMBROVSKYI, H. M. SHEPETKO-DOMBROVSKYI \\ P. Shupyk National Medical Academy of Postgraduate Education \\ Kyiv City Clinical Emergency Care Hospital
}

\section{BIOLOGICAL SEALANT "SULFAKRYLAT" IN LAPAROSCOPIC SURGERY OF PERFORATED DUODENAL ULCER}

\begin{abstract}
У роботі викладено результати лікування 32 пацієнтів із перфоративною виразкою дванадцятипалої кишки із використанням малоінвазивних відеоендоскопічних технологій. Лапароскопічне зашивання перфорації виразки ДПК проведено у 28 (87,5 \%) пацієнтів, у 4 (12,5 \%) було виконано лапароскопічне висічення виразки та сегментарну дуоденопластику. У 19 (59,4 \%) пацієнтів використано клейову композицію “Сульфакрилат” з метою додаткової герметизації лінії швів. Впроваджені методики дають можливість зменшити кількість ускладнень в післяопераційному періоді.

The results of 32 patients' treatment with perforated duodenal ulcer with the use of minimally invasive videoendoscopic technologies are presented in the article. Laparoscopic suturing of perforated duodenal ulcer was performed in 28 (87.5 \%) patients, in 4 (12.5\%) - laparoscopic ulcerectomy and segmental duodenoplasty were performed. In 19 (59.4 \%) patients adhesive composition "Sulfakrylat" was used with the purpose of additional sealing of suture line. The implemented methods offer the opportunity to decrease the number of complications in the postoperative period.
\end{abstract}

У теперішній час значна кількість хворих оперується з приводу перфоративної виразки дванадцятипалої кишки (ДПК). Незважаючи на ефективність Н2-блокаторів, інгібіторів протонної помпи та антигелікобактерну терапію, що успішно застосовуються у лікуванні виразкової хвороби ДПК, кількість операцій з приводу перфоративної виразки не має тенденції до зменшення. Причиною цього є раптовий початок захворювання у хворих з виразкою ДПК, які не дотримуються сучасних схем лікування або страждають від виразкової хвороби з відсутністю типової клінічної картини захворювання, а також застосування нестероїдних протизапальних препаратів, що створюють умови для виникнення такого ускладнення виразкової хвороби, як перфорація. Тому проблема перфоративної виразки ДПК залишається актуальною [1].

Можливості використання та показання до застосування лапароскопічних технологій при перфоративній виразці ДПК поступово розширюються [1, 2].

За даними літератури та клінічними спостереженнями, прогресивним чинником розвитку та використання лапароскопічних операцій у пацієнтів з перфоративною виразкою ДПК є ефективне оперування на виразковому кратері з перфорацією, проведенням санації черевної порожнини та лікування перитоніту в його реактивній фазі $[3,4]$.

Більша частина пацієнтів із перфоративною виразкою ДПК працездатного віку - від 18 до 50 років. А саме тому застосування малоінвазивних відеоендоскопічних технологій $є$ раціональним, враховуючи всі їхні переваги [5].

Одним із шляхів покращення результатів операційних втручань $€$ застосування біологічних клейових композицій з метою профілактики післяопераційних ускладнень. Найбільш ефективними є клей “Сульфакрилат”, створений на основі етилового ефіру а-ціаноакрилової кислоти. Літературні дані вказують на значну ефективніть застосування цього біогерметика, що має бактерицидну дію відносно таких збудників хірургічної інфекції, як кишкова паличка, золотистий стафілокок, протей, синьогнійна паличка, в умовах перитоніту та профілактику можливих ускладнень [6]. 
За даними В. Т. Марченко, клейову герметизацію лінії швів використовували після ушивання перфоративної виразки шлунка на фоні розлитого гнійного перитоніту. Застосування клею ефективне для профілактики неспроможності швів при великій зоні інфільтрації навколо перфоративного отвору [7].

Використання синтетичного біогерметика в малоінвазивній відеоендоскопічній хірургії при перфоративній виразці забезпечує надійний гемостаз, герметизацію швів та профілактику ускладнень в післяопераційному періоді [8].

Таким чином, використання клею “Сульфакрилат” при малоінвазивних відеоендоскопічних операціях є перспективним напрямком у лікуванні перфорації виразки ДПК, який зменшує ризик виникнення післяопераційних ускладнень.

Мета роботи: застосування клейової композиції “Сульфакрилат” при малоінвазивних лапароскопічних операціях у пацієнтів з перфоративною виразкою ДПК.

Всі представлені операційні втручання виконано на клінічних базах кафедри хірургії та судинної хірургії Національної медичної академії післядипломної освіти імені П. Л. Шупика та Київської міської клінічної лікарні швидкої медичної допомоги. Оперовано 32 пацієнти $з$ перфоративною виразкою ДПК із застосуванням лапароскопічних технологій та використанням біогерметика “Сульфакрилат".

Чоловіків було 27 (84,4 \%), жінок - 5 (16,6 \%). Вік пацієнтів становив від 18 до 52 років.

Усім хворим у передопераційному періоді був проведений стандартний комплекс загальноклінічних та інструментальних обстежень, що включав: загальний аналіз крові, групу крові та резус-фактор, загальний аналіз сечі, біохімічний аналіз крові, електрокардіограму, оглядову рентгенографію органів черевної та грудної порожнини, ультразвукове дослідження органів черевної порожнини.

У 19 пацієнтів (59,4 \%) діагностовано перфорацію виразки передньої стінки ДПК, 6 (18,8 \%) пацієнтів мали перфоративну виразку передньоверхньої стінки ДПК та 7 пацієнтів (21,8 \%) - перфорацію виразки передньо-нижньої стінки. Діаметр перфорації становив від 2 до 6 мм.

Місцевий серозний перитоніт був у 19 (59,4 \%) пацієнтів, місцевий серозно-фібринозний перитоніт - у 5 (15,5 \%), розлитий серозно-фібринозний перитоніт - у 6 (18,8 \%), дифузний серозно-фібринозний перитоніт - у 2 (6,3 \%).

Для доступу в черевну порожнину використовували 10-міліметровий троакар, встановлений вище чи нижче пупка, через який вводили лапа- роскоп та оглядали черевну порожнину. Встановлення портів у черевну порожнину проводили в таких точках: п'ятиміліметровий троакар розташовували зверху по серединній лінії, біля мечоподібного відростка та зліва від серпоподібної зв'язки, 10- та 5-міліметрові троакари по правій та лівій середньоключичній лінії нижче хрящів X ребер на 3 см відповідно. Троакар під мечоподібним відростком використовували з метою встановлення ретрактора для підняття правої та лівої часток печінки та візуалізації ДПК. Порти по середньоключичних лініях використовували для маніпуляцій на виразковому кратері.

Основними етапами лапароскопічної операції були визначення локалізації перфоративної виразки ДПК та усунення перфорації, санація черевної порожнини.

3 метою огляду слизової оболонки задньої стінки ДПК та виключення “дзеркальної виразки” 29 (90,6 \%) пацієнтам було проведено інтраопераційну трансдуоденальну відеоскопію через перфоративний отвір виразки додатковою відеокамерою 3,8 мм, яка не виявила патології (Патент на корисну модель № 99334 від 10.11.2014 “Спосіб інтраопераційної трансдуоденальної відеоскопії під час відеоендоскопічних операцій при перфоративній виразці дванадцятипалої кишки”).

Враховуючи розмір перфоративного отвору, відсутність інфільтративних змін стінки ДПК у 28 $(87,5$ \%) пацієнтів було виконано лапароскопічне зашивання перфорації виразки ДПК. У 4 (12,5 \%) пацієнтів виконано лапароскопічне висічення виразки та сегментарну дуоденопластику.

Технологія зашивання перфорації виразки ДПК полягала в тому, що в черевну порожнину через 10-міліметровий порт подавали плетену нитку із поліетилентерефталату діаметром №3-0, що не розсмоктується, з двома голками, після чого кожною голкою окремо виконували проколювання стінки ДПК з боку перфоративного отвору в симетричних точках в напрямку від слизової до серозної оболонки. Наступним етапом проводили зав'язування вузла.

3 метою додаткової герметизації зашитої перфорації виразки ДПК, особливо при зашиванні перфоративного отвору двома або трьома швами, використовували клейову композицію “Сульфакрилат”, яка складається із трьох компонентів (ефір а-ціаноакрилової кислоти, що полімеризується при контакті з середовищами, які містять воду; сополімер; метакрилат-3-оксисульфалан, що має антибактеріальну активність) і наносилася на лінію зашивання ендоскопічною голкою в об'ємі 0,03 мл (1 крапля) на 1 см² поверхні, що обробля- 


\section{ПОВІДОМЛЕННЯ}

ється. Полімеризація клею відбувалась протягом 10-120 с з утворенням еластичної плівки, що створювала щільне змикання серозних оболонок стінки ДПК, яка має бактерицидні властивості. Біогерметик “Сульфакрилат” використовували у 15 (46,9 \%) пацієнтів після зашивання перфоративної виразки та у 4 (12,5 \%) хворих після лапароскопічної дуоденопластики, далі проводили пробу на герметичність.

Санацію черевної порожнини виконували таким чином: у черевну порожнину нагнітали 0,9 \% фізіологічний розчин до 4-5 л до рівня повного занурення кишечника в об’єм розчину. Після цього встановлювали додатковий порт у правій здухвинній ділянці із введенням у порожнину малої миски дренажу, через який відбувалась аспірація рідини під тиском, що створений карбоксиперитонеумом. Заключну евакуацію рідини із черевної порожнини виконували відсмоктувачем із встановленням дренажів у підпечінковий простір через 10-міліметровий порт справа та малу миску через 5-міліметровий порт правої здухвинної ділянки.

\section{СПИСОК ЛІТЕРАТУРИ}

1. Soreide K. Current insight into pathophysiology of gastroduodenal ulcers: Why do only some ulcers perforate? [Електронний ресурс] / Kjetil Soreide // Journal of Trauma and Acute Care Surgery. - 2016. - Режим доступу до ресурсу : http://journals.lww.com/jtrauma/pages/articleviewer.aspx?year= $9000 \&$ issue $=00000 \&$ article $=99582 \&$ type $=$ abstract .

2. Evidence-based clinical practice guidelines for peptic ulcer disease 2015 / K. Satoh, J. Yoshino, T. Akamatsu [et al.] // Journal of Gastroenterology. - 2016. - № 51. - P. 177-194.

3. Тутченко М. І. Ефективність мініінвазивних технологій у невідкладній хірургії / М. І. Тутченко, О. В. Васильчук, С. М. Піотрович // Хірургія України. - 2013. - № 2. - С. 86-89. 4. Лупальцов В. І. Шляхи поліпшення результатів лікування перитоніту на сучасному етапі / В. І. Лупальцов, А. І. Ягнюк // Клінічна хірургія. - 2015. - № 4. - С. 32-36.

5. Epidemiology of perforated peptic ulcer: Age- and gender - adjusted analysis of incidence and mortality / K. Thorsen, J. A. Soreide, J. T. Kvaloy [et al.] // World Journal of Gastroenterology. - 2013. - № 19. - P. 347-354.
У післяопераційному періоді пацієнти отримували інгібітори протонної помпи. Антигелікобактерну терапію призначали згідно з IV Маастрихтською угодою. Тривалість перебування в стаціонарі коливалась в межах від 6 до 8 діб.

Таким чином, малоінвазивні відеоендоскопічні операції ефективно застосовуються у пацієнтів із перфоративною виразкою ДПК працездатного віку з розміром перфоративного отвору до 6 мм. Використання клейової композиції в ділянці ушивання перфорації виразки або дуоденопластики значно підвищує їх міцність та створює асептичні умови для загоєння лінії шва в умовах перитоніту.

Висновки. 1. Застосування малоінвазивних відеоендоскопічних технологій набуває все більшого впровадження в хірургічному лікуванні перфоративної виразки ДПК.

2. Додаткова герметизація клейовою композицією “Сульфакрилат” швів при перфорації виразки ДПК дає можливість уникнути ускладнень у післяопераційному періоді.

6. Медицинский клей “Сульфакрилат”. Антибактериальная противовоспалительная клеевая композиция / Т. В. Марченко, Н. Н. Прутовых, Г. А. Толстиков, А. Г. Толстиков // Новосибирск. - 2013. - С. 7-48.

7. Марченко Т. В. Применение новых технологий с использованием сульфакрилата в детской хирургии [Електронний ресурс] / Т. В. Марченко. - Режим доступу до ресурсу : http:// sulfakrilat.com.ua/wpcontent/uploads/2014/04/\%D0\%B4\%D0\% B5\%D1\%82\%D1\%81\%D0\%BA\%D0\%B0\%D1\%8F\%D1\%85\% D0\%B8\%D1\%80\%D1\%83\%D1\%80\%D0\%B3\%D0\%B8\%D1\% 8F.pdf.

8. О возможности улучшения результатов реконструктивной хирургии желудочно-кишечного тракта [Електронний ресурс] / [В. В. Плечев, С. Л. Шилов, И. И. Шарипов и др.]. - Режим доступу до ресурсу : http://sulfakrilat.com.ua/wp-content/ uploads/2014/04/\%D0\%A0\%D0\%B5\%D0\%BA\%D0\%BE\%D0 \%BD\%D1\%81\%D1\%82\%D1\%80\%D1\%83\%D0\%BA\%D1\%82 \%D0\%B8\%D0\%B2\%D0\%BD\%D0\%B0\%D1\%8F\%D1\%85\%D 0\%B8\%D1\%80\%D1\%83\%D1\%80\%D0\%B3\%D0\%B\%D1\%8F\%D0\%96\%D0\%9A\%D0\%A2.pdf.

Отримано 17.05.16 